Достоевский и мировая культура. Филологический журнал. 2021. № 2 (14). Dostoevsky and World Culture. Philological journal, no. 2 (14), 2021.

Научная статья / Research Article

УДК 821.161.1.0

ББК 84 ( 2 Рос=Рyс)

https://doi.org/10.22455/2619-0311-2021-2-37-64
This is an open access article distributed under the Creative Commons Attribution 4.0 International (CC BY 4.0)

(C) 2021. А.Г. Гачева

Институт мировой литературы им. А.М. Горького

Российской академии наук, Москва, Россия

«Идеал есть у меня, дан, Христос»:

Христология Достоевского в контексте

традиции нравственного истолкования догмата

(C) 2021. Anastasia G. Gacheva

A.M. Gorky Institute of World Literature of the

Russian Academy of Sciences, Moscow, Russia

\title{
"I Have an Ideal, it Was Given me: Christ": Dostoevsky's Christology in the Context of the Tradition of Moral Interpretation of Dogma
}

Информация об авторе: Анастасия Георгиевна Гачева, доктор филологических наук, ведущий научный сотрудник, Институт мировой литературы им. А.М. Горького Российской академии наук, ул. Поварская, д. 25а, 121069 г. Москва, Россия.

https://orcid.org/0000-0001-5453-0881

E-mail: a-gacheva@yandex.ru

Благодарности: Исследование выполнено при финансовой поддержке РФФИ в рамках научного проекта № 18-012-90023.

Аннотация: Статья продолжает серию исследований, посвященных богословию Ф.М. Достоевского в контексте традиции нравственного истолкования догмата, которая сложилась в русской мысли XIX - первой трети XX века. В центре внимания - христология Достоевского, представленная сквозь призму идеи обращения догмата в заповедь. Показано, что представление Достоевского о Христе как «идеале человека во плоти» должно рассматриваться не в контексте утопической мысли, а как манифестация идеи обожения человека, как вы- 
ражение святоотеческой максимы: «Бог вочеловечился, чтобы мы обожились». Сквозь призму христологического догмата рассмотрена полемика Ф.М. Достоевского с К.Д. Кавелиным. Показано, как утверждение равноправности двух природ, Божественной и человеческой, во Христе влияет на антропологию и историософию Достоевского. Рассмотрены взгляды современников писателя, развивавших идею нравственного истолкования догмата о Богочеловеке: архим. Феодора (Бухарева), еп. Иоанна (Соколова), Н.Ф. Федорова, архим. Антония (Храповицкого), В.И. Несмелова, С.Н. Булгакова.

Ключевые слова: творчество Ф.М. Достоевского, догматика, этика, нравственная идея догмата, христология, философский и богословский контекст.

Для цитирования: Гачева А.Г. «Идеал есть у меня, дан, Христос»: Христология Достоевского в контексте традиции нравственного истолкования догмата // Достоевский и мировая культура. Филологический журнал, 2021. № 2 (14). С. 37-64. https://doi.org/10.22455/2619-0311-2021-2-37-64

Information about the author: Anastasia G. Gacheva, D.Sc. in Philology, Head Researcher, A.M. Gorky Institute of World Literature of the Russian Academy of Sciences, 25A Povarskaya St., Moscow 121069, Russia.

https://orcid.org/0000-0001-5453-0881

E-mail: a-gacheva@yandex.ru

Acknowledgements: The reported study was funded by the Russian Foundation for Basic Research (RFBR), project no. 18-012-90023.

Abstract: The present article continues a series of studies devoted to the theology of Fyodor Dostoevsky in the context of the tradition of moral interpretation of dogma, which was developing in Russian thought during the $19^{\text {th }}$ century and the first third of the $20^{\text {th }}$ century. The article focuses on Dostoevsky's Christology, presented through the prism of the idea of transforming dogma into a commandment. It is shown that Dostoevsky's perception of Christ as the "ideal man in flesh" should be understood not in the context of utopian thought, but as a manifestation of the idea of the deification of man, as expressed in the patristic aphorism: "For the Son of God became man so that we might become God." Dostoevsky's polemic with Konstantin Kavelin is discussed from the point of view of the Christological dogma. It is illustrated how the assertion of the equality of the two natures, Divine and human, in Christ affects the anthropology and historiosophy of Dostoevsky. Views of writer's contemporaries who developed the idea of a moral interpretation of the dogma of the God-man, such as: archimandrite Fedor (Bukharev), bishop Ivan (Sokolov), Nikolay Fedorov, archimandrite Antony (Khrapovitsky), Viktor Nesmelov, Sergey Bulgakov are also considered.

Keywords: Dostoevsky's creative works, dogmatics, ethics, moral idea of dogma, Christology, philosophical and theological context.

For citation: Gacheva, A.G. "'I Have an Ideal, it Was Given me: Christ': Dostoevsky's Christology in the Context of the Tradition of Moral Interpretation of Dogma”. Dostoevsky and World Culture. Philological journal, no. 2 (14), 2021, pp. 37-64. https://doi.org/10.22455/2619-0311-2021-2-37-64 (In Russ.) 
Знаменитая запись от 16 апреля 1864 г., сделанная Достоевским у гроба первой жены, трактовалась в философском и богословском контексте неоднократно ${ }^{1}$. При этом именно применительно к христологии Достоевского она вызывала наибольшее число вопросов. Камнем преткновения оказывались слова писателя о Христе как «идеале человека во плоти», «вековечном от века идеале, к которому стремится и по закону природы призван стремиться на земле человек» [Достоевский, 1972-1990, т. 20, с. 172]. В самой попытке применить к образу Второго Лица Троицы, в богословских и богослужебных текстах называемому «Сын Божий», «Сын Человеческий», «Господь наш Иисус Христос», «Агнец», «Спаситель мира и Спас душ наших», идущее от светской философской традиции понятие «идеал», исследователи были склонны видеть отзвуки увлечения Достоевского утопическим социализмом, идеями петрашевцев, для которых, как убедительно показала Ф.Г. Никитина, Христос был образом идеального человека, нравственным мерилом жизни и действия, но никак не Богочеловеком, поправшим смерть [Никитина, 2005].

Наиболее отчетливо данный подход был представлен в статье И.А. Кирилловой, давшей разбор записи «Маша лежит на столе...» с точки зрения сложного сплетения в ней «утопических и христианских мотивов». Мысль Достоевского, утверждает И.А. Кириллова, «раздваивается»: «Слова “Один Христос мог”, сказанные в подтверждение тезиса о невозможности человеку в его наличной природе исполнить заповедь о любви, «предполагают упование на преображающегося Христа Богочеловека, Которого Достоевский неизменно исповедует сердцем (в Святоотеческом понимании), но в тексте он тут же Его определяет как “Идеал человека во плоти”, как “вековечный от века идеал... к которому стремится и по закону природы должен стремиться человек” - определения, четко суммирующие гуманистическую, утопическую концепцию Христа», транслирующие «концепцию сен-симонистов и рационалистические истолкования Евангельского образа Христа у Фейербаха, Прудона, Штрауса и позднее Ренана, как “обожествленного” людьми человека» [Кириллова, 1997, с. 23].

Стоит при реконструкции богословских взглядов писателя последовать этой логике, и сразу же выйдешь к кажущемуся очевидным решению: увидеть в словах о Христе как «вековечном от века идеале»

1 Одна из последних - развернутых - трактовок представлена Т.А. Касаткиной [Касаткина, 2019]. 
сугубый акцент на Его человеческой природе, нарушающий принцип равночестности Божества и человечества, равноправности во Христе двух природ, соединенных, по определению IV Вселенского собора, «неслитно, неизменно, нераздельно, неразлучно» [Деяния, 1895, с. 109]. И тогда эти слова предстанут еще одним свидетельством «пелагианства» писателя, в чем, опираясь на проповедь старца Зосимы о всемирной любви, упрекал его прот. Павел Хондзинский [Павел Хондзинский, прот., 2014, с. 141; Павел Хондзинский, прот., 2017, c. 335].

Однако, соблазняясь столь легким, на поверхности лежащим решением, мы невольно (или сознательно) забываем о том, что сам Достоевский резко протестовал против редукции образа Спасителя мира, против стремления представителей католической и протестантской гуманистической критики считать Христа только «простым человеком, благотворным философом» [Достоевский, 1972-1990, т. 11, с. 179]. Полемике с подобным взглядом посвящен роман «Идиот» [см. об этом в сб.: Роман Ф.М. Достоевского «Идиот», 2001; Касаткина, 2003; Степанян, 2005, с. 153, 422-432], она же переходит на знаменитые «фантастические страницы» подготовительных материалов к роману «Бесы» [Круглый стол, 2004, c. 70-71; Степанян, 2005, с. 96; Гачева, 2013], о чем в достоевистике существует большая литература. Более того, для писателя, как и для героев, скрещающих мировоззренческие копья на страницах его романов, вопрос о Христе ставится буквально как «или - или»: «или вера, или жечь» [Достоевский, 1972-1990, т. 11, с. 182], или Богочеловечность, открывающая полноту развития человечности, или человечность, лишенная Божественного измерения, а значит безнадежно тождественная самой себе, неспособная к трансцензусу, к расширению за свои границы, обреченная на «вечность “на аршине пространства”, которую с «мертвящей тоской» предчувствует Родион Раскольников, отделивший себя от Бога и от людей [Достоевский, 1972-1990, т. 6, с. 327]. Соединение двух этих ответов для писателя исключено, примирительный компромисс между ними онтологически невозможен, поэтому неизбежно придется искать иные объяснения, почему в записи у гроба первой жены ко Христу применяется понятие «идеал». Придется самим определять смысловое его наполнение, ибо оно для писателя отнюдь не равнялось тому, что вкладывали в понятие «идеал» представители просвещенческой и романтической эстетики. 
Кажущиеся противоречивыми, сочетающими несочетаемое выражения «Христос есть вековечный от века идеал», «идеал человека во плоти» звучат совершенно иначе, как только они оказываются извлечены из чуждого им контекста утопической мысли и поставлены в иной, родственный, аутентичный контекст, поняты как проявления той традиции нравственного истолкования догмата, которая утверждается в русской богословской и философской мысли во второй половине XIX в. и затем переходит в XX век. Достоевский, как ранее нам уже приходилось писать, является одним из ключевых представителей этой традиции, писателем-богословом, активно участвовавшим в ее формировании [Гачева, 2019, с. 66-68, 72-77], его влияние испытали митр. Антоний Храповицкий, В.С. Соловьев, В.И. Несмелов, С.Н. Булгаков, а Н.Ф. Федоров в заочном диалоге с писателем развивал идею обращения догмата в заповедь, заостряя ее в духе идей активного христианства.

Когда мы начинаем рассматривать слова о Христе как «идеале человека во плоти» в свете трактовки догмата как того, что должно быть не просто исповедано, но исполнено, должно стать правилом жизни, они предстают как манифестация темы обожения, той заповеди о совершенстве, которую Бог дает человеку, призывая к ее исполнению всех: «Будьте совершенны, как совершен Отец ваш Небесный» (Мф. 5, 48). Это отнюдь не попытка редуцировать образ «Спасителя и источника жизни» до «общечеловека», отвлеченного моралиста - тип, который был органически чужд Достоевскому, воспринимался как теоретический и ходульный, невсамделишный, сочиненный («люди из бумажки»). Это попытка утвердить Христа подлинным мерилом и основанием преображения человека, о чем Достоевский прямо скажет в подготовительных материалах к роману «Бесы»: «Да Христос и приходил за тем, чтоб человечество узнало, что земная природа духа человеческого может явиться в таком небесном блеске, в самом деле и во плоти, а не то что в одной только мечте и в идеале, что это и естественно и возможно» [цит. по: Тихомиров, 2000, с. 234].

В приведенном фрагменте слово «идеал» употребляется полемически - в духе этики Канта, для которого идеал, задавая направление самосовершенствованию человека, в то же время принципиально невоплотим. Но иначе трактуется «идеал» в записи от 16 апреля 1864 г.: это не отвлеченная идея нравственного совершенствования, но живая Личность, а достижение идеала означает полноту преоб- 
ражения, облечения «в $я$ Христа», вхождения в Его «синтетическую натуру», пресуществления бытия из смертного, разрозненного, страдающего в бессмертное, всеединое, исполненное блаженства, где «мы будем - лица, не переставая сливаться со всем» [Достоевский, 1972-1990, т. 20, с. 174].

Запись «Маша лежит на столе...» отчетливо демонстрирует, что идея нравственного истолкования догмата не сводится у Достоевского к христианской морали, к кодексу заповедей, к Нагорной проповеди, как бы религиозно высока она ни была. Нравственное делание, состоящее в любви и жертве, рассматривается писателем в его неразрывности с духо-телесной метаморфозой, венчающей процесс перерождения нынешнего смертного, атомарного, внутренне разорванного, самостного, эгоистически свернутого на себе существа «в другую натуру», вхождения «в жизнь окончательную, синтетическую, бесконечную» [Достоевский, 1972-1990, т. 20, с. 174]. Это совсем не то исполнение нравственного долга, которого требуют от человека моралисты, эмансипирующие мораль от религии. Подобные попытки перед лицом падшего, смертного порядка природы, утверждающегося в своей незыблемости, с точки зрения Достоевского, безнадежны: в этой картине мира Христос - человек, Он не воскрес и воскреснуть не может. Более того - нравственные усилия «я», лишенного надежды и упования, оборачиваются мучительной раздвоенностью и отчаянием, от которых один шаг до преступления и самоубийства.

Богочеловечность Христа - залог богочеловечности человечества. Эта мысль настойчиво повторяется в подготовительных материалах к роману «Бесы». «Многие думают, что достаточно веровать в мораль Христову, чтобы быть христианином. Не мораль Христова, не учение Христа спасет мир, а именно вера в то, что Слово плоть бысть. <...> Надо именно верить, что это окончательный идеал человека, все воплощенное слово, Бог воплотившийся» [Достоевский, 1972-1990, т. 11, с. 188]. В свете этого утверждения обретают новый смысловой объем те пассажи диалогов Князя и Шатова, в которых этика буквально выводится из факта Боговоплощения, а «подражание Христу» приводит к созиданию Царства Христова: «Из Христа выходит та мысль, что главное приобретение и цель человечества есть результат добытой нравственности. Вообразите, что все Христы, - ну возможны ли были бы теперешние шатания, недоумения, пауперизм? Кто не понимает этого, тот ничего не понимает в Христе 
и не христианин. Если б люди не имели ни малейшего понятия о государстве и ни о каких науках, но были бы все как Христы, возможно ли, чтоб не было рая на земле тотчас же?» [Достоевский, 1972-1990, т. 11, с. 192-193].

Фраза, возникающая в середине цитаты: «Кто не понимает этого, тот ничего не понимает в Христе и не христианин», не просто акцентирует идею обращения догмата в заповедь, выдвигая ее в центр разговора, но привлекает внимание к тому, что должно стать итогом этого обращения, всецелого и всеобщего «облечения во Христа». Это «рай на земле», «миллениум», в котором «не будет жен и мужей» [Достоевский, 1972-1990, т. 11, с. 182]. Возникает мотив онтологического перерождения, преображения не только психической, но и физической природы людей. Достоевский, опираясь на слова Христа о том, что в Царствии Небесном «не женятся и не посягают», но пребывают, «как ангелы Божии на небесех» (Мф. 22, 30), развивает заявленную еще в записи от 16 апреля 1864 г. мысль о трансформации существующих форм муже-женского союза, характерных для наличного, послегрехопадного естества, о преодолении «гендерных» разделений, обретении целостной, неповрежденной природы. Религиозно-этический императив писателя заключает требование полноты преображения, когда не только духовно, но и физически будут «все как Христы».

«Фантастические страницы» подготовительных материалов к роману «Бесы» впервые были опубликованы в 1906 г. С.Н. Булгаковым в юбилейном собрании сочинений писателя. В «Очерке о Достоевском», предварявшем это собрание, Булгаков, один из тех мыслителей, которые начинают в культуре XX в. традицию религиозно-философского осмысления творчества Достоевского, указывал на их ключевое значение для понимания его позиции как богослова, который «веровал не в отвлеченный образ Иисуса, стерилизованный Кантом и отпрепарированный новейшей критикой протестантизма, не в еврейского раввина, учителя морали, но в воплотившееся Слово, в Бога, пришедшего во плоти, и в этой вере видел всю сущность христианства» [Булгаков, 1996, с. 191].

Этика Достоевского уводит от автономной, самоопорной этики, которая эмансипируется от религии и рождает идеал из глубин разумной человеческой воли, ставя его перед личностью как побуждающий ее действие образ, но при этом, подобно миражу-оазису в жаркой пустыне, постоянно отодвигающийся по мере движения 
навстречу ему. Писатель резко выступает против подобной иллюзорной «приманки», он утверждает этику Богочеловечества, требующую полноты обожения, полноты воплощения образа совершенства. Только сквозь призму Халкидонского догмата обретают подлинный объем и масштаб слова писателя о Христе как «начале всякого нравственного основания» [Достоевский, 1972-1990, т. 11, с. 185].

Трактовка догмата о Богочеловеке как камени не только веры, но и совершеннолетнего действия человека, стала одной из центральных в полемике Ф.М. Достоевского с оппонентами его «Пушкинской речи». Ранее мы уже приводили развернутую цитату из ответа писателя А.Д. Градовскому [Гачева, 2018, с. 66-67], в котором он утверждал органическую, неразрывную связь идеалов «общественных гражданских» «с идеалами нравственными», подчеркивая, что последние рождаются из религиозной идеи, несущей в себе образ совершенства [Достоевский, 1972-1990, т. 26, с. 165]. Там же звучала формула: «самосовершенствование и есть исповедание полученной религии», прямо выражающая идею обращения догмата в заповедь, утверждающая, что исповедовать религиозную истину значит ее исполнять, воплощать заложенный в ней образ совершенства. Однако статья-комментарий к «Пушкинской речи» вызвала несогласие со стороны одного из ведущих представителей русского западничества - историка и публициста К.Д. Кавелина, который подверг сомнению как раз тезис о том, что нравственные идеи, рождаясь из религиозного чувства, в свою очередь порождают социальные модели развития, определяют суть и значение общественных идеалов. К.Д. Кавелин утверждал, что дело обстоит совершенно иначе: первичны не идеи нравственно-религиозные, а выработанные человеком правила общежития, следование которым является основой становления и воспитания нравственности. Эти правила служат необходимыми предпосылками формирования у личности «внутреннего сознания добра и зла, иначе говоря, голоса совести», который и руководит человеком в его жизни и действии, удерживая от негодных поступков и побуждая творить добро [Кавелин, 2010, с. 460].

Достоевский категорически не согласен с Кавелиным. Предложенный критерий нравственности кажется ему зыбким. Он относителен, зависим от той или иной формы общественной жизни, от условий существования людей в разных концах земли и в разных национальных организмах, а значит в принципе неспособен быть 
универсальным, касающимся каждой личности вне зависимости от внешних условий существования и определяемых этими условиями жизненных установок. А главное - в нравственности, вырастающей в окружении относительных правд, колеблется понятие о добре и зле: оно перестает быть абсолютным, касающимся «всякого человека, приходящего в мир», оно варьируется, меняет свое содержание, его очертания и границы колеблются, понятия, сформированные у конкретного человека и в конкретном обществе вступают в противоречие с теми, которые выработаны другими людьми и в других социальных моделях. И наконец, понятие о добре и зле, с точки зрения Достоевского, прямо связано с состоянием человеческого сердца, определяется степенью его поврежденности и степенью осознания того, что твое сердце повреждено. «Совесть, совесть маркиза де Сада!» [Достоевский, 1972-1990, т. 27, с. 56] - и совесть героя «Жития великого грешника», совесть Лужина и совесть Митеньки Карамазова, когда он видит сон в Мокром, совесть Петруши Верховенского и совесть Сонечки Мармеладовой - рождают различные, если не противоположные понимания добра и зла. Да и в одном и том же человеке совесть может проявлять себя совершенно по-разному, и влияют на это, с точки зрения Достоевского, не общественные обстоятельства, а зрячесть/незрячесть сердца, его способность увидеть в ближнем Христа и исполнить по отношению к нему заповедь о любви. Как художник и «тайнозритель» человеческого сердца Достоевский рисует разные состояния совести Родиона Раскольникова, Смердякова, Ивана Карамазова, героя «Кроткой» - в начале, середине, конце их личной истории, и разнятся они именно тем, насколько запечатали эти герои храмины собственных душ, способны они или нет открыть «вся внутренняя своя» свету, льющемуся «из миров иных», и стать проводниками этого света в мир.

Утверждая иную модель становления и развития нравственности, опирающуюся на единство догмата и заповеди, Достоевский записывает: «Недостаточно определять нравственность верностью своим убеждениям. Надо еще беспрерывно возбуждать в себе вопрос: верны ли мои убеждения? Проверка же их одна - Христос» [Достоевский, 1972-1990, т. 27, с. 56]. Он выставляет Христа как абсолютное мерило этики, и не только самый образ Христа, но и его действия и поступки. «Нравственный образец и идеал есть у меня, дан, Христос» [Достоевский, 1972-1990, т. 27, с. 56]. Более того, проводит своего рода мысленный эксперимент, откликаясь на полемический 
пассаж Кавелина, иронически замечавшего, что логика Достоевского приводит к тому, чтобы назвать безнравственным фанатика, думавшего «служить Богу, сожигая еретиков на костре» и законно причисленного католической церковью к лику святых [Кавелин, 2010, с. 462]: «Сожигающего еретиков я не могу признать нравственным человеком, ибо не признаю ваш тезис, что нравственность есть согласие с внутренними убеждениями. Это лишь честность <...>, но не нравственность. Нравственный образец и идеал есть у меня, дан, Христос. Спрашиваю: сжег ли бы он еретиков - нет. Ну так значит сжигание еретиков есть поступок безнравственный» [Достоевский, $1972-1990$, т. 27, с. 56].

Критерий нравственности для Достоевского единственен и универсален. Как и в записи у гроба первой жены, это Богочеловеческая Личность Христа. Христос и Христов образ - тот свет истины и совершенства, который влечет к себе людей, открытых сердцем, по-евангельски «чающих движения воды» (Ин. 5, 3). Когда же их действие подчиняется не Христу, а личному убеждению, могут произойти поистине страшные вещи: «Взрываю Зимний дворец, разве это нравственно? Совесть без Бога есть ужас. Она может заблудиться до самого безнравственного» [Достоевский, 1972-1990, т. 27, с. 56].

Споря с Кавелиным, полагающим в основу нравственности убеждения человека, Достоевский выдвигает на первый взгляд парадоксальную мысль: «иногда нравственнее бывает не следовать убеждениям, и сам убежденный, вполне сохраняя свое убеждение, останавливается от какого-то чувства и не совершает поступка. Бранит себя и презирает умом, но чувством, значит совестью, не может совершить и останавливается (и знает, наконец, что не из трусости остановился)» [Достоевский, 1972-1990, т. 27, с. 57]. Примечательно, что инстанцией, останавливающей личность от совершения поступка, диктуемого «убеждением», выступает здесь та же «совесть». Но это совесть иначе настроенная - не по дребезжанию «убеждения», в которое то и дело врываются фальшивые ноты, а по абсолютному звучанию Слова Христова, исходящего из уст Спасителя мира.

К.Д. Кавелин со всей убежденностью заявляет, что не только личный, но и общественный идеал не нуждается ни в каком религиозном обосновании. Достоевский, напротив, вводит в сферу религиозного исповедания и религиозного делания человека и тот, и другой. Звучащая на фантастических страницах подготовительных материалов к роману «Бесы» формула истинной веры: «Каяться, себя созидать, 
царство Христово созидать» [Достоевский, 1972-1990, т. 11, с. 177], соединяющая личное и общее делание, ведущая от первого ко второму, претворяется на страницах «Братьев Карамазовых» в проповедь деятельной любви и апологию общества, преображающегося в Церковь. Для человека, исполняющего завет «любить <... ближних деятельно и неустанно» [Достоевский, 1972-1990, т. 14, с. 52], критерий нравственности только Христос-Богочеловек, в поэме Ивана Карамазова воскрешающий умершую девочку и в Алешином видении Каны Галилейской разделяющий с человечеством трапезу любви. Для общества, преображающегося из «союза почти еще языческого во единую вселенскую и владычествующую Церковь» [Достоевский, 1972-1990, т. 14, с. 61], - только Троица, неслиянно-нераздельное единство Божественных Лиц. И не случайно последняя сцена романа, где мальчики и Алеша, собравшиеся у Илюшина камушка, клянутся вечно помнить умершего и «никогда не забывать друг о друге», заключив каждого из собравшихся «в свое сердце» [Достоевский, 1972-1990, т. 15, с. 196], исследователями Достоевского уже давно представляется как сцена рождения Церкви.

При этом, соотнося и соединяя друг с другом догмат о Богочеловеке с догматом о Троице, Достоевский не разделяет механически сферы действия обоих догматов по принципу отнесения первого только к личности и второго - только к человеческой общности. И тот и другой догмат в равной степени относятся им и к отдельному человеку, и к человечеству, которое есть не безликая масса, а множество лиц, живых, конкретных «я». Исполнить нравственную заповедь, заключенную в догмате о Богочеловеке, уподобиться Христу в любви и жертве можно, только соборуясь с другими людьми, соединяясь с ними в братски-любовное, неслиянно-нераздельное целое, т. е. воплощая в своей жизни и действии принцип Троицы, став, как будет писать современник и заочный собеседник Достоевского Н.Ф. Федоров, «многоединством или всеединством» [Федоров, 1995-2000, т. 1, с. 90]. И наоборот: только объединяясь по образу и подобию Троицы, поставив себе Ее как образец - идеал - совершенного общежития, обретается возможность для каждой личности исполнить заповедь «Будьте совершенны...»

Вера в богочеловечность Христа не только определяет для Достоевского нравственное поведение личности и облик общественного строительства, но и задает вектор развития искусства, определяет пути движения словесного творчества. Запись, появляющуюся в под- 
готовительных материалах к роману «Братья Карамазовы»: «Человек есть Воплощенное Слово. Он явился чтобы сознать и сказать» [Достоевский, 1972-1990, т. 15, с. 205]. К.А. Степанян рассматривает как манифестацию творческого метода Достоевского, его «реализма в высшем смысле» [Степанян, 2012], подчеркивая, что истина Боговоплощения рождает художественный императив: «при полном реализме найти в человеке человека» [Достоевский, 1972-1990, т. 27, c. 65]. В.Н. Захаров, считающий «реализм в высшем смысле» одной из версий «христианского реализма» русской литературы, отмечает: «Как эстетический принцип христианский реализм появился задолго до открытия художественного реализма в искусстве. Он проявляется в новозаветной концепции мира, человека, в двойной (человеческой и Божественной) природе Мессии» [Захаров, 2001, с. 10]. Связь «реализма в высшем смысле» с темой Боговоплощения, с тем, что «слово плоть бысть» (Ин. 1, 14), отмечают и Т.А. Касаткина [Касаткина, 2004], и Б.Н. Тихомиров. Разбирая знаменитые слова писателя об «осанне, проходящей через большое горнило сомнений» и полагая в ней «эстетическую формулу» его творчества, он привлекает внимание к высказыванию В.В. Зеньковского, утверждавшего, что «вера в человека у Достоевского <...> торжествует именно при погружении в самые темные движения человеческой души» [Зеньковский, 1991, c. 238]. «Именно такая точка зрения, - подчеркивает исследователь, - помогает понять неслучайность своеобразного оксюморона, который присутствует в хрестоматийной формуле писателя: “...Я <...> реалист в высшем смысле, то есть изображаю все глубины души человеческой» [Тихомиров, 2012, с. 12-13]. Представленное здесь погружение в «глубины души человеческой», в «самые темные» ее движения есть не что иное как параллель кенозису Слова, схождению Бога в самые глубины поврежденной, темной материальности, в самые недра человеческого естества, чтобы их высветлить и преобразить, утвердить в подлинной, светоносной реальности, открыть человечеству путь к обожению, материи - перспективу преображения в Богоматерию.

Звучащее в подготовительных материалах к предсмертному выпуску «Дневника писателя» 1880 г. credo писателя: «Идеал есть у меня, дан, Христос» - еще одна формула «реализма в высшем смысле», совершающего труд обращения догмата в заповедь в сфере литературы. Подобно Христу, показавшему, как в Боге может преобразиться каждый живущий, Достоевский открывает каждому герою 
перспективу преображения, он, по точному выражению К.А. Степаняна, «уже здесь, на земле, видит человека и человечество в будущей полноте Небесного Иерусалима» [Степанян, 2005, с. 101], самой манерой письма показывает, что «в человеке может вместиться Бог» [Достоевский, 1972-1990, т. 25, с. 228].

Одно из важнейших богословских понятий, соединенных с учением о Богочеловеке и прямо определивших становление в русской культуре традиции нравственного истолкования Халкидонского догмата, - понятие синергии. В земной жизни Христа обе Его природы, божественная и человеческая, и обе связанные с ними воли не просто находятся в единстве друг с другом, но действуют совместно и равноправно. Все свои дела на земле Христос творит одновременно как Бог и как человек, и этот синергизм, проявивший себя в вочеловечении Божества, был раскрыт в традиции русской мысли и культуры в действенном, активно-христианском ключе. История в ее деонтологии была понята как поле соработничества Бога и человека, как «работа спасения», «восстановления мира в то благолепие нетления, каким он был до падения» [Федоров, 1995-2000, т. 1, с. 401], в которой человечество, пришедшее «в разум истины», должно принести благой плод Творцу. Как пишет философ, литературовед С.Г. Семенова, размышляя о Христе как «Центрообразе русской мысли и литературы», именно этот образ «в высокой рефлексии русской религиозной философии открывает высшую христианскую надежду на синергию Бога, человека и природы в ее глубинных творчески-органических ресурсах, возможность согласного действия Божественной и человеческой воли (как то было в отношениях двух природ в Спасителе)» [Семенова, 2012, с. 187].

Богочеловеческая синергия движет художественное творчество. И именно она является главным принципом построения художественного мира у Достоевского, создания образа, который, как пишет Т.А. Касаткина, «двусоставен», всегда строится так, что внутри «временного, внешнего образа» «открывается образ внутренний, вечный, воспроизводящий события священной истории» [Касаткина, 2015, с. 435]. Смысл этой двусоставности, по утверждению Т.А. Касаткиной, определяется внутренним заданием новозаветной истории - привести мир к спасению, спасение же невозможно без полноты человеческого соучастия. «Евангелие - это манифестация чудес там, где с волей Господней сотрудничала воля человеческая; и это несостоявшиеся чудеса - там, где такого сотрудничества не 
было. Чтобы спасение осуществилось - очевидно, мы должны досовершить в нашей истории несостоявшиеся по нашей вине чудеса. Именно по этой причине история движется - движется вперед - а не повторяется и не воспроизводится - и движется к своему окончанию - к тому моменту, когда спасение, совершенное Богом, будет, наконец, досовершено и человеком» [Касаткина, 2015, с. 439].

Очевидно, что под досовершением спасения человеком разумеется не автономное, самостийное действие, в котором человек узурпирует не принадлежащее ему право и активничает без хозяина. «Досовершить» спасение после Боговоплощения значит досовершить его вместе с Богом. Иначе это не будет спасение и иначе оно не будет довершено. Образ же досовершения задан заветом Христа апостолам: «Ходя же, проповедуйте, что приблизилось Царство Небесное; больных исцеляйте, прокаженных очищайте, мертвых воскрешайте, бесов изгоняйте» (Мф. 10, 7-8) и другим Его словом, сказанным на Тайной Вечере: «Истинно, истинно говорю вам: верующий в Меня, дела, которые творю Я, и он сотворит, и больше сих сотворит» (Ин. 14, 12). Для русской религиозной философии, от Н.Ф. Федорова до С.Н. Булгакова, эти слова стали указанием на необходимость соработничества рода людского своему Творцу в преображении мира в Царство Христово, «вплоть даже до человеческого участия во всеобщем воскресении, согласно "проекту" Н.Ф. Федорова» [Булгаков, 1933, с. 465]. Достоевский, хотя и не апеллирует к ним прямо, безусловно, их «держит в уме», проявляя вложенный в них смысл то в речах героев («мыслю, что мы со Христом это великое дело решим» [Достоевский, 1972-1990, т. 14, с. 288]), то в символических сценах романов, подобно той, что завершает главу «Кана Галилейская», где Алеша, павший на землю «слабым юношей», встает «твердым на всю жизнь бойцом» [Достоевский, 1972-1990, т. 14, с. 328], то в прямом публицистическом слове, как звучащее в «Пушкинской речи» пророчество о «великой, общей гармонии, братском окончательном согласии всех племен по Христову евангельскому закону» [Достоевский, 1972-1990, т. 26, с. 148]. Это пророчество, это исповедание Достоевского В.С. Соловьев поставил в контекст темы эсхатологического преображения мира, воцарения «нового неба и новой земли», торжества Иерусалима Небесного, резко выступив против К.Н. Леонтьева, обвинившего писателя чуть ли не в секулярном утопизме. Младший собеседник писателя подчеркивал святоотеческие корни его историософии и антропологии, 
утверждая, что вера Достоевского «в человека и в человечество» базировалась на вере «в богочеловека и в богочеловечество - в Христа и в Церковь» и приводя в доказательство слова св. Афанасия Великого, «что в Христе Бог стал человеком для того, чтобы человека сделать богом» [Соловьев, 1988, т. 2, с. 321-322].

Упреки К.Н. Леонтьева Достоевскому в приверженности «автономической морали» [Леонтьев, 1912, с. 188] бьют мимо цели, ибо человек в его мире вообще не действует самостийно. Его действие не монологично, оно всегда синергично. Там, где герой - как Сонечка Мармеладова, Алеша Карамазов, старец Зосима - действует с живым ощущением стояния перед лицом Божиим («Что ж бы я без Бога-то была?» [Достоевский, 1972-1990, т. 6, с. 248]), в его воле и действии присутствует Бог. Там, где герой стремится опираться на свою волю («вся воля моя»- как заявляет Кириллов), он на самом деле незаметным для себя образом отдает эту волю. Только отдает ее не Христу, а иному, тому, кого в новозаветных текстах называют «имущим державу смерти, сиречь диаволом» (Евр. 2, 14).

Именно поэтому так возмущала Достоевского утверждаемая К.Д. Кавелиным мысль об автономии совести. Ему было внятно, что совесть, как и другие чувства и действия человека, принципиально синергична - в ней совместно с человеком может действовать Бог, а может - Его антагонист и разрушитель. И герои писателя постоянно демонстрируют образ этой синергии внутри человеческой совести как Иван Карамазов, который первоначально убедил свою совесть в том, что многозначительно сообщить Смердякову о своем отъезде в Чермашню вовсе не означает открыто дать разрешение на убийство отца, а затем - когда стало ясно, что убил Смердяков, испытал муки прозревшей совести: «<...> если только он убил, а не Дмитрий, то, конечно, убийца и я» [Достоевский, 1972-1990, т. 15, с. 54].

В мире Достоевского человек, проходя свой земной путь, буквально в каждой точке этого пути совершает одновременно онтологический и нравственный выбор - с кем он действует в данный конкретный момент - со Христом или с чертом - тем самым мелким чертом-приживальщиком, который подкараулил Родиона Раскольникова и подсунул ему топор, а затем закружил в безумном вихре ложных идей жителей губернского города в романе «Бесы». С подобного ракурса слова Дмитрия Карамазова о сердцах людей, которые являются «полем битвы» «дьявола с Богом» [Достоевский, 1972-1990, т. 14, 100] выглядят совсем не риторической фразой. 
Особенно явственно эта битва за сердце человека видна на примере Кириллова. Там, где герой совершает пусть мелкие, но исполненные живым смыслом поступки, жесты «родственного внимания» к ближним: играет с ребенком хозяйки, хлопочет во время родов жены Шатова, затем посылает «старуху “поздравить”, а роженице передает столь необходимого для подкрепления сил «бульону с белым хлебом», котлет и горячего чаю, вместе с ним и через него действует Бог. Когда же он заявляет: «Если Бог есть, то вся воля Его, и из воли Его я не могу. Если нет, то вся воля моя, и я обязан заявить своеволие» [Достоевский, 1972-1990, т. 10, с. 454, 470], то тут же вверяет эту эмансипированную волю черту и соработает с ним, совершая только одно - саморазрушающее и невольно разрушающее других - действие: кончает с собой. И в других, не столь крайних и явных случаях Достоевский показывает, как своеволие оборачивается чужеволием. Стремясь опираться лишь на свою самость, на свою одинокую гордынную волю, герой свивается в углу и подполье: он закапсулирован, в нем действует закон эгоизма, закон атомарного, раздробленного бытия, которое цепко держит в своих руках «имущий державу смерти». В то время как действуя, подобно Христу, по принципу: «Не моя воля, но Твоя да будет», он становится соработником Творца мира.

С точки зрения религиозной невозможности автономии «я» (эта автономия «призрачна» и на деле есть скрытое и не преодолимое на эгоистических путях рабство злу) расширяется у Достоевского и объем понятия «жертвы». Христос - абсолютная, истекающая из полноты любви Жертва за мир, это предел кенозиса, «истощания» и крестной смерти ради того, чтобы не погиб ни один из рожденных женами. Именно к такой полноте жертвы призван, по Достоевскому, человек. И в каждой его жертве, сколь бы внешне мала и ничтожна она ни была, присутствует и действует Бог.

Синергическое действие человека и человечества с Богом в истории реализует сотериологический смысл, заложенный в догмате о двух природах и двух волях во Христе. Его ареал и охват, по мысли Достоевского и его философско-богословских собратьев, должен совпасть с границами мира. Ибо идея обращения догмата в заповедь касается не только нравственного поведения человека и нравственных оснований устроения человеческих обществ. Она касается всего спектра действия человека в мире: экономики, политики, педагогики, медицины, науки. Когда Достоевский в подгото- 
вительных материалах к роману «Братья Карамазовы» записывает заглавными буквами: «ТОГДА НЕ ПОБОИМСЯ И НАУКИ. ПУТИ ДАЖЕ НОВЫЕ В НЕЙ УКАЖЕМ» [ДостоевскиЙ, 1972-1990, т. 15, 250], он задает вектор развития новой науки, которую спустя всего несколько лет В.С. Соловьев назовет «всемирной медициной», подчеркивая, что она должна исцелить и «омертвевшую природу», и «страждущее человечество» [Соловьев, 1997, с. 40]. А затем идея обращения догмата в заповедь станет идеей всецелого оцерковления жизни, которую будут развивать философы русского религиозно-философского ренессанса и представители богословия XX в., несмотря на все катаклизмы истории, на углубляющийся разрыв между миром и храмом, на воинствующий атеизм пореволюционной эпохи.

Какие философы и богословы были собратьями Достоевского в трактовке догмата о Богочеловеке как основания человеческого действия в бытии и истории? Из современников - архим. Феодор (Бухарев), еп. Иоанн (Соколов), Н.Ф. Федоров, В.С. Соловьев, митр. Антоний (Храповицкий), из тех, кто в ХХ в. продолжал традицию нравственного истолкования христологического догмата, прежде всего В.И. Несмелов и С.Н. Булгаков. Все они стремились дать свой ответ на вопрос: «Какое значение для нравственной жизни имеет вера в Иисуса Христа как Бога?» [Антоний (Храповицкий), 1900 , с. 96]. Именно так была озаглавлена статья митр. Антония Храповицкого, написанная в 1896 году как реакция на утверждение Л.Н. Толстого о нелепости христианских догматов и их бесполезности для нравственной жизни. Митр. Антоний выступил против подобного разведения догматики и этики, подчеркивая гуманистическую редукцию образа Спасителя у Э. Ренана, Д. Штрауса и самого Толстого. Он буквально воспроизвел аргументацию Достоевского против французской «пищеварительной философии», легко признающей факт, что Христос не воскрес, и подчеркнул: чтобы одушевить и направить внутреннюю работу личности и ее внешнее действие, Христос должен быть больше, чем человек, Он должен быть Богом. Пастырь Церкви и богослов, митр. Антоний на новом витке представил спор Достоевского с кантовской этикой, автономизирующей человека и объявляющей идеал принципиально невоплотимым в реальности. Раскрывая нравственный смысл догмата о Богочеловеке для исторической жизни рода людского, он говорил о необходимости, с одной стороны - личного подвига, а с другой - созидания совершенного союза людей, ибо каждый человек призван к святости 
и, следуя за Христом, человек одновременно становится частью Тела Христова - Церкви.

Впрочем, еще до митр. Антония нравственная трактовка догмата о Богочеловеке, тесно связанная с трактовкой догмата об искуплении, звучала как в светской, так и в церковной среде. Архим. Феодор (Бухарев), богослов, ученый, мыслитель, стремившийся «связать христианство с живой жизнью, актуализировать в сознании современников образ Христа, приблизить его к людям» [Ашимбаева, 2012 , с. 268], в серии статей «О современности в отношении к православию», обратился к вопросу о том, что дает ныне живущему человеку вера в Сына Божия, восприявшего «человеческое естество с человеческою волею и действием человеческим», «человеческими мыслями, желаниями, чувствами, воспоминанием, воображением», соединившегося с человеческой телесностью во всей ее полноте. По убеждению богослова, образ Христа вочеловечившегося, явившего полноту духоматериальности и одновременно полноту действия, противостоит спиритуалистическим тенденциям в вере, «мнимой духовности, отвлеченной идеальности и мечтательным парениям» [Феодор (Бухарев), архим., 1991, с. 69], обратной стороной которых является равнодушие и презрение к миру. А главное - пример Христа дает основание многообразной активности человека, высветляя и преображая ее, вводя в орбиту христианского действия все сферы дела и творчества человека - не только церковное служение, но и «гражданскую службу», и «земледелие», и «занятия купли и продажи», и даже «общества и увеселения» [Феодор (Бухарев), архим., 1991, с. 69]. Христова истина, подчеркивал архим. Феодор, должна быть «раскрываема и разъясняема в значении начала для всего, и самого дольнего и мирского, то есть в том самом значении, в каком истина явилась нам в лице самого Христа, снисшедшего с неба на землю и даже во ад сходившего для открытия всюду своего животворного света» [Феодор (Бухарев), архим., 1991, с. 70].

Среди богословов - современников Достоевского, в представлении которых человек должен обрести полноту соучастия в Божием деле, действуя вместе с Богом, исполняя Его волю в истории созиданием Царства Христова, - безусловно должен быть упомянут епископ Смоленский Иоанн (Соколов), церковный деятель, канонист, при жизни известный как выдающийся проповедник, «импровизатор-богослов». В 1874-1877 гг. в «Христианском чтении» посмертно печатались фрагменты его лекций по догматическому 
богословию, читанные в Санкт-Петербургской духовной академии. И хотя в текстах Достоевского имя о. Иоанна не встречается, можно предположить его знакомство с серией этих статей, тем более что их проблематика близка тем аспектам христианского вероучения, о которых автор «Братьев Карамазовых» напряженно и настойчиво размышлял.

При обращении к лекциям о. Иоанна бросается в глаза его стремление преподносить богословские истины не отвлеченно, a «в связи с учением о личности Христа», открывшего цель и назначение человеческой жизни на земле. Обращаясь к беседе Христа с самарянкой, он специально подчеркивает, что Спаситель «при всякой встрече с человеком выводит человека из его несчастного и приниженного положения и возвышает на такую высоту, что как бы уничтожает между Собой и им расстояние», ибо хочет «видеть не случайные явления в человеке, а человечество, его идеальную сторону» [Иоанн (Соколов), еп., 1874, с. 524]. Разбирая сказанные в этой беседе слова Христа о необходимости поклоняться в духе и истине, богослов замечает, что возможность такого поклонения неразрывно связана с совершенствованием человечества, которое призвано стать достойным Божества. И при этом указывает, что подлинное поклонение разумеет поклонение «всем существом своим»; тем самым позволяя избежать дробления действия и одновременно собрать воедино те силы и энергии личности, которые тратятся и рассеиваются впустую. Служение Христу, подчеркивает еп. Иоанн, «не исключает и того знания, которое принадлежит человеку в кругу естественных предметов», поскольку «наши естественные познания имеют и должны иметь целию» «бесконечную истину» [Иоанн (Соколов), еп., 1874, с. 527].

Одним из ключевых мест лекционного цикла епископа Иоанна был разбор того места Евангелия от Иоанна, где Христос благовествует о воскресении: «Истинно, истинно говорю вам: наступает время, и настало уже, когда мертвые услышат глас Сына Божия и, услышав, оживут. Ибо, как Отец имеет жизнь в Самом Себе, так и Сыну дал иметь жизнь в Самом Себе. И дал Ему власть производить и суд, потому что Он есть Сын Человеческий» (Ин. 5, 25-27). Привлекая внимание к словам Христа о том, что Он, как и Отец, «имеет жизнь в самом себе», еп. Иоанн подчеркивал, что здесь манифестирована такая полнота и сила «внутренней, духовной жизни», которая уже не может не возвышаться «и над условиями физическими», над смер- 
тью и тлением. И далее лектор перекидывал мостик между воскресением Христа и будущим обновлением человечества, подчеркивая, что «струи жизни, протекшие в человечество из жизни Христовой, служат в свою очередь источниками других токов, которые разливаются в человечестве более и более и которые со временем должны обхватить его и совершить его полное обновление». И если «духовная жизнь Спасителя не могла не отразиться и во внешней Его жизни», а главное - в победе над смертью, в воскресении, то «такая жизнь не может не возвысить человека и в самой его жизни физической», ибо «не может быть, чтобы человечество, возвышенное до такой степени духовно, осталось навсегда в том стесненном положении, которое определяется для него естественным или физическим ходом вещей. И действительно, эта жизнь, которую дал Ему Отец, до того дойдет, что и мертвые воскреснут. В самом деле, этот безгранично развивающийся дух жизни в человечестве, при благоприятных условиях, не может не возвыситься над физическими условиями; он, как скоро проникнет в человечество вполне, не может не подчинить себе и законов смерти. Нельзя думать, что это случится только в отдельных явлениях, как это было многократно при жизни Иисуса Христа; эти частные случаи воскрешения мертвых должны были только служить доказательствами присутствия во Христе всеживотворящей силы. Воскрешенные Им опять умерли, - это знак, что для нескончаемой жизни потребно благоприятное воздействование и со стороны мира физического, - чтобы в самой природе не было места для смерти; а для этого должна наступить особая эпоха, которую Христос относит к концу мира» [Иоанн (Соколов), 1875, с. 533-534].

Еп. Иоанн акцентировал деятельный, проективный подход к идее финала истории. Мысль об активности человека в деле спасения прямо вытекала из данной им трактовки евангельских слов: «И дал Ему власть производить и суд, потому что Он есть Сын Человеческий» (Ин. 5, 27). Человек, будучи создан по образу и подобию Божию, «носит в себе начала суда и правды» - а потому в своей истории человечество «постепенно развивает из себя эти понятия, и должно само определить суд над собой», руководствуясь идеалом совершенства, данным в образе «Верховного существа». Однако процесс уяснения «суда и правды», неразрывно связанный с осознанием своего назначения в мире, медленен и труден - налицо физическое и духовное несовершенство человека, его зависимость от гибельного порядка вещей. И тем не менее этот процесс должен прийти к своему 
завершению, иначе земному человечеству не останется иного исхода, кроме «всеобщей и окончательной смерти». Причем правда, основанная на сверхприродном законе, чтобы дать человечеству реальную почву спасения, не может быть внесена извне, напротив, должна возникнуть из самой его среды. И вот во Христе, в естестве Которого человеческая природа равноправна с божественной, Который есть не только «совершенный Бог», но и «совершенный человек», не только «Сын Божий», но и «Сын Человеческий», эти правда, идеал и обетование являются во всей полноте, открывая человечеству путь к тому «бесконечному совершенству», совершенству духовно-телесному, над которым уже не властны силы смерти и тления и которого требует от своих сынов Отец Небесный [Иоанн (Соколов), еп., 1874, c. 538-539].

Знакомство Ф.М. Достоевского с трудами о. Иоанна (Соколова) можно только предполагать. Зато с ними был знаком другой современник писателя уже из философского лагеря - Н.Ф. Федоров. В своих текстах, касающихся действенной трактовки догмата, понимания его как заповеди - как проекта, регулятивного образца для человека и человечества, он прямо ссылался на отца Иоанна, особенно выделяя начало его цикла лекций - «О Лице Иисуса Христа».

Для Федорова догмат о двух природах и двух волях во Христе воплощал прежде всего завет общего дела, образ соработничества божественной и человеческой энергий и воль в главном «деле дел» христианства - воскрешении всех когда-либо живших, при котором нет доминирования первой, но есть полнота равенства и родства. Христос в Самом Себе являет образец Богочеловеческой синергии, и он должен быть усвоен и воплощен в процессе истории, распространившись на весь человеческий род. «Показывая, что Христос был не только Бог, но и действительный человек, - пишет Федоров, - тем самым доказывалась и необходимость деятельности самого человека в деле воскрешения, и не только нравственной, но и умственной, и физической, материальной. Соединяя во Христе два естества, две воли, двойное действие, тем самым признавали необходимость в деле искупления, или воскрешения, двух воль, действующих в полном согласии» [Федоров, 1995-2000, т. I, с. 160].

Именно представление о том, что человек должен быть соработником Творца на земле позволяет, по Федорову, дать прямой ответ на вопрос, почему за воскресением Христа, победителя смерти, не последовало воскресения всех. «Мы должны, - пишет мыслитель, - 
представить воскрешение как действие еще неоконченное. <...> Христос ему начаток, чрез нас оно продолжалось, продолжается и доселе. Воскрешение не мысль только, но и не факт, оно проект <...> как Божественное оно уже решено, как человеческое еще не произведено» [Федоров, 1995-2000, т. I, с. 142]. «Если смотреть на историю как на осуществление “Благой Вести”, то станет ясно, что если всеобщее воскрешение и не совершилось вслед за Воскресением Христа, то оно за ним следует, что Воскресение Христа есть начаток всеобщего Воскрешения, а последующая история - продолжение его» [Федоров, 1995-2000, т. I, с. 146].

Достоевский, познакомившийся с идеями Н.Ф. Федорова в конце жизни, отреагировал на близкое ему самому требование активного отношения к вере, не просто исповедания догматических истин, но их осуществления во всей полноте. Тот же подход к христианской догматике, призванной стать этикой, воплотиться в реальности, и у его младшего современника В.С. Соловьева, который спустя год после кончины писателя в «Трех речах в память Достоевского» движется от христологии к антропологии, утверждая понятие Богочеловечества, прямо вытекающее из догмата о двух природах и двух волях во Христе и одновременно задающее человечеству, мечущемуся между «идеалом мадонны» и «идеалом содомским», перспективу бытийного роста.

Для Достоевского, Федорова, Соловьева размышление о человеке неотъемлемо от идеи духо-телесного преображения. Образ Христа, зримо явившего на Фаворе, каким светоносным, прекрасным, сияющим может быть земное естество, предстает у них как подлинная норма человеческого. А рядом с темой обожения человека звучит тема родственно-любовного попечения человека о твари, преображения всей природы, которую они также рассматривают сквозь призму христологического догмата. Христос, подчеркивает в «Трех речах...» Соловьев, своим вочеловечением и крестным подвигом возвращает царское достоинство не только человеку, но и всему природному миру. И по-настоящему «верить в царство Божие» значит «с верой в Бога соединять веру в человека и веру в природу» [Соловьев, 1988, т. 2, с. 313]. В ином случае разрыв между человеком, миром и Богом приводит к тому, что «природа, отделенная от духа Божия», оказывается «мертвым и бессмысленным механизмом без причины и цели», а «Бог, отделенный от человека и природы, вне своего положительного откровения», оказывается высокопар- 
ной идеей, ненужным, «пустым отвлечением» [Соловьев, 1988, т. 2, c. 313].

Понятие Богочеловечества содержит в себе идею многоединства и в этом смысле неразрывно с понятием Церкви, с идеей воссоединения человечества по образу и подобию Триединого Божества. Эта внутренняя связь - догмата о Троице и догмата о двух природах и двух волях во Христе - станет основой всего богословского дискурса русской мысли второй половины XIX-XX вв., связанного с идеей обращения догмата в заповедь.

В капитальном труде «Наука о человеке» (1905-1906) профессор Казанской духовной академии В.И. Несмелов, утверждая неразрывность в христианском вероучении «догматики и этики, веры и жизни», писал: «Для того чтобы быть христианином и членом Божия царства, недостаточно лишь исповедовать апостольскую веру во Христа, а непременно нужно и жить по истине апостольской веры, как и наоборот - не достаточно лишь стремиться к жизни по содержанию евангельских заповедей во имя их практической пригодности для жизни людей, а непременно еще нужно и верить во Христа, как в истинного Спасителя мира и в действительного творца вечной жизни, т.е. нужно исповедовать апостольскую веру в него» [Несмелов, 1905-1906, т. 2, с. 375]. Нагорная проповедь и Истина Воскресения взаимообусловлены, одно не может существовать без другого. Несмелов предостерегал от частой редукции, происходящей в обыденном сознании по отношению к нравственным заповедям Христа, когда они понимаются не в контексте Божественного домостроительства, а «лишь с точки зрения их пригодности для настоящей жизни людей» [Несмелов, 1905-1906, т. 2, с. 375]. Так в свое время Достоевский горько иронизировал над теплохладностью обывателя, употребляющего христианство «для послеобеденного спокойствия и удобства пищеварения» [Достоевский, 1972-1990, т. 11, с. 180], для того чтобы покомфортнее устроиться в наличном земном бытии, тщательно закрывая глаза на его взрывчатый, смертный фундамент, в то время как эта дерзновенная, горячая вера не оставляет камня на камне от половинчатой, приспособленческой, удобной морали мира, желающего забыть о своей поврежденности. И Несмелов, следуя той же позиции, настаивает на том, что христианская нравственность может быть понята (и исполнена) в полноте своего значения только в контексте «догматического учения о Божием спасении мира» [Несмелов, 1905-1906, т. 2, с. 375]. Только истина Богочеловечества 
и Воскресения есть подлинный и абсолютный критерий этики христианства.

Заданное традицией нравственного истолкования догмата восхождение от христологии к антропологии, от Богочеловека к Богочеловечеству, в трудах философа и богослова, прот. Сергия Булгакова дополняется центральной для его мысли софиологической темой. Отношение «Бог»- «человек» разворачивается в заданный Достоевским, Федоровым, Соловьевым трехчлен «Бог, человек и природа» [Федоров, 1995-2000, т. 1, с. 388]. Софиология, по мысли Булгакова, «является вопросом о силе и значении Богочеловечества и притом не только Богочеловека как воплотившегося Логоса, но именно Богочеловечества как единства Бога со всем сотворенным миром - в человеке и через человека» [Булгаков, 1996, с. 269]. Тем самым, подчеркивает мыслитель, преодолевается манихейское, дуалистическое миросознание с его непреодолимой пропастью между Творцом и творением, и в то же время противоположная крайность - всеобъемлющий пантеизм, растворяющий Бога в природе, обожествляющий наличное состояние мира с его круговоротом смертей и рождений, а значит не нуждающийся ни в Боговоплощении, ни в искуплении.

По мысли Булгакова, софиология, неразрывная с христологией, позволяет избежать двух крайностей мироотношения, единых, как лицо и изнанка. С одной стороны, это бегство из апостасийного мира, отрекшегося от Творца и стремительно идущего к гибели, с другой «рабство этому миру», гордо объявившему себя самоцелью. Обе позиции частичны, дробны, противоположны целостной истине Богочеловечества, стремящейся к высветлению и спасению всего в бытии. Столь же частичны и паллиативны, с точки зрения Булгакова, прямо следующего в данном случае Достоевскому, и принципы папоцезаризма, соединяющего христианство и жизнь «посредством подчинения последней могущественной церковной организации» [Булгаков, 1996, с. 270]: это приводит лишь к внешнему соединению, но никак не меняет состояния человеческих душ, не гармонизирует раздробленного, хаотичного мира. Бессильно, по мысли Булгакова, и социальное, филантропическое христианство. Оно всецело озабочено решением локальных задач, не осознавая главной христианской задачи, суть которой «оправдание мира в Боге» - в противовес тому отделению «мира от Бога, которое фактически проповедуется» [Булгаков, 1996, с. 270]. Полнота этого оправдания, по мысли Бул- 
гакова, заключена в «Догмате Богочеловечества»: он еще не принят церковным сознанием, но философская и богословская мысль уже до него дозрела, и движется она к нему через Халкидонский догмат, через истину Боговоплощения, через то, что «Слово плоть бысть» [Булгаков, 1996, с. 271]. Догмат о Богочеловечестве - по-настоящему вселенский, космический, корни которого достигают «до глубины земли и неба, до сокровенных тайн Св. Троицы и тварной природы человека», которая изначально софийна [Булгаков, 1996, с. 271]. Путь от его исповедания к исполнению равен соборованию человечества, преображению мира в Царство Христово.

\section{Список литературы}

1. Антоний (Храповицкий), еп., 1900 - Антоний (Храповицкий), еп. Полное собрание сочинений: в 3 т. Казань, 1900. Т. 2.445 с.

2. Антоний (Храповицкий), митр., 1965 - Антоний (Храповицкий), митр. Ф.М. Достоевский как проповедник возрождения. Монреаль: Издание Северо-Американской и Канадской епархии, 1965. 311 c.

3. Ашимбаева, 2012 - Ашимбаева Н.Т. Архимандрит Феодор (Бухарев) и Достоевский // Достоевский: философское мышление, взгляд писателя. СПб.: Дмитрий Буланин, 2012. С. 267-276.

4. Булгаков, 1933 - Булгаков С.Н. Агнец Божий. О Богочеловечестве. Ч. 1. Париж: YMCA-press, 1933. 468 c.

5. Булгаков, 1996 - Булгаков С.Н. Тихие думы. М.: Республика, 1996. 509 с.

6. Гачева, 2013 - Гачева А.Г. Антропология Ф.М. Достоевского (религиозно-философский аспект) // Ф.М. Достоевский: писатель, мыслитель, провидец. Сб. научных статей. М.: ПСТГУ, 2013. C. 109-126.

7. Гачева, 2019 - Гачева А.Г. Творчество Ф.М. Достоевского и проблема нравственного истолкования догмата о Троице в русском богословии XIX - первой трети XX века // Достоевский и мировая культура, 2019, № 3. С. 52-87.

8. Достоевский 1972-1990 - Достоевский Ф.М. Полн. собр. соч.: в 30 т. Л.: Наука, 1972-1990.

9. Деяния, 1895 - Деяния Вселенских Соборов, изданные в русском переводе при Казанской духовной академии. Казань: Университет. тип., 1895. Т. 4. 692 с.

10. Захаров, 2001 - Захаров В.Н. Христианский реализм в русской литературе (постановка проблемы) // Евангельский текст в русской литературе XVIII - XX веков: цитата, реминисценция, мотив, сюжет, жанр: сборник научных трудов. Вып. 3. Петрозаводск: ПетрГУ, 2001. (Проблемы исторической поэтики; Вып. 6). С. 5-20.

11. Захаров, 2008 - Захаров В.Н. Фантастические страницы Достоевского // Евангельский текст в русской литературе XVIII - XX веков: цитата, реминисценция, мотив, сюжет, жанр: Сборник научных трудов. Вып. 5. Петрозаводск: ПетрГУ, 2008 (Проблемы исторической поэтики; Вып. 8). С. 385-397. 
12. Иоанн (Соколов), 1874 - Иоанн (Соколов). О Лице Иисуса Христа: мысли покойного преосвященного Иоанна, епископа смоленского, бывшего ректора и проф. догматики в нашей академии. I-III // Христианское чтение. 1874. № 12. С. 517-541.

13. Кавелин, 2010 - Кавелин К.Д. Избранное. М.: РОССПЭН, 2010. 608 с.

14. Касаткина, 2003 - Касаткина Т.А. Комментарии // Достоевский Ф.М. Собр. соч.: в 9 т. М., 2003. T. 4. C. 594-602.

15. Касаткина, 2004 - Касаткина Т.А. 0 творящей природе слова. Онтологичность слова в творчестве Ф.М. Достоевского как основа «реализма в высшем смысле». М.: ИМЛИ РАН, 2004. 479 с.

16. Касаткина, 2015 - Касаткина Т.А. Священное в повседневном: Двусоставный образ в произведениях Ф.М. Достоевского. М.: ИМЛИ РАН, 2015. 529 с.

17. Касаткина, 2019 - Касаткина Т.А. Достоевский как философ и богослов: художественный способ высказывания. М.: Водолей, 2019. 336 с.

18. Кириллова, 1997 - Кириллова И. «Маша лежит на столе...» - утопические и христианские мотивы (к обозначению темы) // Достоевский и мировая культура. Альманах, 1997. № 9. С. 22-27.

19. Леонтьев, 1912 - Леонтьев К.Н. Собр. соч.: в 9 т. М.: В.М. Саблин, 1912. Т. 8.357 с.

20. Несмелов, 1905 - Несмелов В.И. Наука о человеке: в 2 т. Казань: Центральная типография, 1905. T. 1.418 c.

21. Никитина, 2005 - Никитина Ф.Г. Федор Достоевский, Валериан Майков, Алексей Плещеев об Иисусе Христе (40-е годы XIX века) Достоевский: Дополнения к комментарию. М.: Наука, 2005. С. 314-326.

22. Павел Хондзинский, прот., 2014 - Павел Хондзинский, прот. Достоевский как «учитель церкви» // Вестник Русской христианской гуманитарной академии. 2014. Т. 15. № 2. С. 137-146.

23. Соловьев, 1988 - Соловъев В.С. Сочинения: в 2 т. М.: Мысль, 1988.

24. Соловьев, 1997 - Соловьев В.С. [Об истинной науке] // Исследования по истории русской мысли. Ежегодник за 1997 год / публ., вступ. ст., примеч. А.П. Козырева. СПб.: Алетейя, 1997. С. 31-68.

25. Степанян, 2005 - Степанян К.А. «Сознать и сказать»: «Реализм в высшем смысле» как творческий метод Достоевского. М.: Раритет, 2005. 512 с.

26. Тихомиров, 2000 - Тихомиров Б.Н. Заметки на полях Академического полного собрания сочинений Достоевского (уточнения и дополнения) // Достоевский и мировая культура. Альманах, 2000, № 15. С. 231-241.

27. Тихомиров, 2012 - Тихомиров Б.Н. «..Я занимаюсь этой тайной, ибо хочу быть человеком»: Статьи и эссе о Достоевском. СПб.: Серебряный век, 2012. 504 с.

28. Федоров, 1995-2000 - Федоров Н.Ф. Собрание сочинений: в 4 т. М.: Прогресс-Традиция, 1995-2000.

\section{References}

1. Antonii (Khrapovitskii), ep. Polnoe sobranie sochinenii [Complete Works]. Vol. 2. Kazan', 1900. 445 p. (In Russ.)

2. Antonii (Khrapovitskii), mitr. F.M. Dostoevskii kak propovednik vozrozhdeniia [Fyodor Dostoevsky as a Preacher of Renewal]. Montreal, Izdanie Severo-Amerikanskoi i Kanadskoi eparkhii Publ., 1965. 311 p. (In Russ.) 
3. Ashimbaeva, N.T. "Arkhimandrit Feodor (Bukharev) i Dostoevskii" ["Archimandrite Theodore (Bukharev) and Dostoevsky"]. Dostoevskii: filosofskoe myshlenie, vzgliad pisatelia [Dostoevsky: Philosophical Thinking, Writer's View], Saint-Petersburg, Dmitrii Bulanin Publ., 2012, pp. 267-276. (In Russ.)

4. Bulgakov, S.N. Agnets Bozhii. O Bogochelovechestve [Lamb of God. About the God-man]. Vol. 1. Paris, Ymca-press Publ., 1933. 468 p. (In Russ.).

5. Bulgakov, S.N. Tikhie dumy [Quiet Thoughts]. Moscow, Respublika, 1996. 509 p. (In Russ.)

6. Gacheva, A.G. "Antropologiia F.M. Dostoevskogo (religiozno-filosofskii aspekt)" ["Fyodor Dostoevsky's Anthropology (Religious and Philosophical Aspects)"]. F.M. Dostoevskii: pisatel', myslitel', providets. Sbornik nauchnykh statei [Fyodor Dostoevsky: Writer, Thinker, Seer. Collected Articles], Moscow, PSTGU Publ., 2013, pp. 109-126. (In Russ.)

7. Gacheva, A.G. "Tvorchestvo F.M. Dostoevskogo i problema nravstvennogo istolkovaniia dogmata o Troitse v russkom bogoslovii XIX - pervoj treti XX veka (Stat'ia pervaia)" [“The Heritage of F.M. Dostoevsky and the Problem of Moral Interpretation of the Doctrine of the Trinity in Russian Theology of the 19th - First Third of the 20th century (Article One)"]. Dostoevskii i mirovaia kul'tura. Filologicheskii zhurnal, no. 3, 2019, pp. 52-87. (In Russ.).

8. Dostoevskii, F.M. Polnoe sobranie sochinenii v 30 t. [Complete Works in 30 Vols]. Leningrad, Nauka Publ., 1972-1990. (In Russ.)

9. Deianiia Vselenskikh Soborov, izdannye v russkom perevode pri Kazanskoi dukhovnoi akademii [Acts of the Ecumenical Councils, Published in Russian Translation at the Kazan Theological Academy]. Vol. 4. Kazan', Universitet. tip. Publ., 1895. 692 p. (In Russ.)

10. Zaharov, V.N. "Khristianskii realism v russkoi literature (postanovka problemy)” ["Christian Realism in Russian Literature (a Statement of the Problem)"]. Problemy istoricheskoj poetiki, issue 6, 2001, pp. 5-20. (In Russ.).

11. Zaharov, V.N. "Fantasticheskie stranitsy Dostoevskogo" ["Dostoevsky's Fantastic Pages"]. Problemy istoricheskoi poetiki, issue 8, 2008, pp. 385-397. (In Russ.).

12. Ioann (Sokolov). "O Litse Iisusa Khrista: mysli pokoinogo preosviashchennogo Ioanna, episkopa smolenskogo, byvshego rektora i prof. dogmatiki v nashei akademii. I-III." ["About the Face of Jesus Christ: Thoughts of the Late Right Reverend John, Bishop of Smolensk, Former Rector and Professor of Dogmatics in Our Academy. I-III"]. Khristianskoe chtenie, no. 12, 1874, pp. 517-541. (In Russ.)

13. Kavelin, K.D. Izbrannoe [Izbrannoe]. Moscow, ROSSPEN Publ., 2010. 608 p. (In Russ.)

14. Kasatkina, T.A. "Kommentarii" ["Commentary"]. Sobranie sochinenii [Collected works] by F.M. Dostoevsky, vol. 4, Moscow, 2003, pp. 594-602. (In Russ.)

15. Kasatkina, T.A. O tvoryashchej prirode slova. Ontologichnost' slova v tvorchestve F.M. Dostoevskogo kak osnova "realizma v vysshem smysle" [On the Creative Nature of the Word. Ontology of the Word in the Works of Fyodor Dostoevsky as the Fundament of "Realism in the Highest Sense"]. Moscow, IWL RAS Publ., 2004. 479 p. (In Russ.).

16. Kasatkina, T.A. Sviashchennoe v povsednevnom: Dvusostavnyi obraz v proizvedeniiakh F.M. Dostoevskogo [The Sacred in the Ordinary: the Two-Folded Image in Dostoevsky's Works]. Moscow, IWL RAS Publ., 2015. 529 p. (In Russ.).

17. Kasatkina, T.A. Dostoevskii kak filosof i bogoslov: khudozhestvennyi sposob vyskazyvaniia [Dostoevsky as a Philosopher and Theologian: the Artistic Way of Expression]. Moscow, Vodolei Publ., 2019. 336 p. (In Russ.).

18. Kirillova, I. "'Masha lezhit na stole...' - utopicheskie i khristianskie motivy (k oboznacheniiu temy) [“'Masha lies on the table...: Utopian and Christian Motifs (Towards a Description of the Theme)]. Dostoevskii i mirovaia kul'tura. Al'manakh, no. 9, 1997, pp. 22-27. (In Russ.) 
19. Leont'ev, K.N. Sobranie sochinenii v 9 tomakh [Collected Works in 9 Vols.]. Vol. 8. Moscow, V.M. Sablin Publ., 1912. 357 p. (In Russ.)

20. Nesmelov, V.I. Nauka o cheloveke 2 tomakh [Human Science in 2 Vols.]. Vol. 1. Kazan', Tsentral'naia tipografiia Publ., 1905. 418 p. (In Russ.)

21. Nikitina, F.G. "Fedor Dostoevskii, Valerian Maikov, Aleksei Pleshcheev ob Iisuse Khriste (40-e gody XIX veka)" ["Fyodor Dostoevsky, Valerian Maikov, Alexey Pleshcheev About Jesus Christ (1940s)"]. Dostoevskii: Dopolneniia k kommentariiu [Dostoevsky: Addenda to the Commentary], Moscow, Nauka Publ., 2005, pp. 314-326. (In Russ.)

22. Khondzinskii, Pavel (prot.) "Dostoevskii kak 'uchitel' tserkvi'." ["Dostoevsky as a 'Teacher for the Church.”.]. Vestnik Russkoi khristianskoi gumanitarnoi akademii, vol. 15, no. 2, 2014, pp. 137-146. (In Russ.)

23. Solov'ev, V.S. Sochineniia: 2 tomakh [Works in 2 Vols.]. Moscow, Mysl' Publ., 1988. (In Russ.)

24. Solov'ev, V.S. [Ob istinnoi nauke] [About True Science]. Issledovaniia po istorii russkoi mysli. Ezhegodnik za 1997 god [Research on the History of Russian Thought. Yearbook for 1997], ed. by A.P. Kozyreva, SaintPetersburg, Aleteiia Publ., 1997, pp. 31-68. (In Russ.)

25. Stepanian, K.A. "Soznat' i skazat”: "Realizm v vysshem smysle" kak tvorcheskii metod Dostoevskogo ["To Know and to Say": "Realism in the Highest Sense" as Dostoevsky's Creative Method]. Moscow, Raritet Publ., 2005. 512 p. (In Russ.)

26. Tikhomirov, B.N. "Zametki na poliakh Akademicheskogo polnogo sobraniia sochinenii Dostoevskogo (utochneniia i dopolneniia)" ["Notes in the Margins of the Academic Complete Works by Dostoevsky (Clarifications and Addenda).”]. Dostoevskii i mirovaia kul'tura. Al'manakh, no. 15, 2000, pp. 231-241. (In Russ.)

27. Tikhomirov, B.N. “...Ia zanimaius' etoi tainoi, ibo khochu byt' chelovekom”: Stat'i i esse o Dostoevskom ["... I am Engaged in This Mystery, Because I Want to be a Man": Articles and Essays about Dostoevsky]. SaintPetersburg, Serebrianyi vek Publ., 2012. 504 p. (In Russ.)

28. Fedorov, N.F. Sobranie sochinenii v 4 tomakh [Collected works in 4 Vols.]. Moscow, Progress-Traditsiia Publ., 1995-2000. (In Russ.)

Статья поступила в редакцию 08.04.2021

Одобрена после рецензирования 20.04.2021

Принята к публикации 21.04.2021

Дата публикации: 25.06.2021
The article was submitted 08 Apr. 2021 Approved after reviewing 20 Apr. 2021

Accepted for publication 21 Apr. 2021

Date of publication: 25 Jun. 2021 